\title{
Method Development and Validation for the Quantification of Acrylamide in Potato Chips and Other Locally Available Food by LC-MS/MS in Bangladesh
}

\author{
Mala Khan, Md. Moniruzzaman, Mamudul Hasan Razu* \\ Designated Reference Institute for Chemical Measurements (DRiCM), Dhaka, Bangladesh \\ Email: *razu_ss86@yahoo.com
}

How to cite this paper: Khan, M., Moniruzzaman, Md. and Razu, M.H. (2019) Method Development and Validation for the Quantification of Acrylamide in Potato Chips and Other Locally Available Food by LC-MS/MS in Bangladesh. Food and Nutrition Sciences, 10, 876-892.

https://doi.org/10.4236/fns.2019.107063

Received: May 13, 2019

Accepted: July 28, 2019

Published: July 31, 2019

Copyright $\odot 2019$ by author(s) and Scientific Research Publishing Inc. This work is licensed under the Creative Commons Attribution International License (CC BY-NC 4.0).

http://creativecommons.org/licenses/by/4.0/

\begin{abstract}
A sensitive, precise, accurate and simple in house validated Liquid Chromatography and Tandem mass spectrometric (LC-MS/MS) analytical method was developed for the quantification of acrylamide in potato chips, a probable carcinogenic and neurotoxic compound in fried food items. Acrylamide was extracted and cleaned up by QuEChERS method, then analyzed by triple quadrupole mass spectrophotometer using positive electrospray-ionization mode and d3-Acrylamide internal standard. The analyte and internal standard were separated on a reversed-phase C18 column $(100 \times 2.0 \mathrm{~mm}, 2.5 \mu \mathrm{m})$ by gradient elution with water and methanol containing $0.1 \%$ formic acid as mobile phase. The analytical method was fully validated by assessment of linearity, specificity, precision, accuracy, selectivity and robustness with relative standard deviation of less than $4 \%$. The calibration curves were found linear with correlation coefficient $\left(\mathrm{r}^{2}\right)$ of 0.9997 over the concentration range $5-500$ $\mu \mathrm{g} / \mathrm{L}$. The recoveries of Acrylamide in the concentration of 250, 400, and 500 $\mu \mathrm{g} / \mathrm{L}$ were $97 \%$ to $104 \%$. Based on the signal to noise ratio, the lower limit of detection (LOD) and lower limit of quantification (LOQ) were achieved 2.0 $\mu \mathrm{g} / \mathrm{L}$ and $4.0 \mu \mathrm{g} / \mathrm{L}$ respectively. The proposed method was also applied to other available most popular 24 types of food (265 number of sample) first time in Bangladesh. The highest level of acrylamide has been found in fried products with the range of $197.04 \mu \mathrm{g} / \mathrm{L}$ to $114.63 \mu \mathrm{g} / \mathrm{L}$, protein-rich food lies between 79.76 to $89.14 \mu \mathrm{g} / \mathrm{L}$ whereas baked food products exhibited less content in the range of 35.23 to $51.17 \mu \mathrm{g} / \mathrm{L}$.
\end{abstract}

\section{Keywords}

LC-MS/MS, Acrylamide, Linearity, Accuracy, Precision, LOD, LOQ 


\section{Introduction}

Food habits are changing rapidly due to variations of lifestyles, economies and global culture. Fried food items have gained its popularity among various age people, especially young generation because of its short time of preparation and consumption. To obtain acceptable food products, it is necessary to maintain nutrients like minerals, carbohydrates, fats, proteins, vitamins, enzymes, etc. But, nutrients may be destroyed or lost when foods are processed because of their sensitivity to heat, light, oxygen, $\mathrm{pH}$ of the solvent or a combination of these [1]. Even some protein quality, micronutrients, vitamin and amino acid can be reduced during frying of food [2]. Furthermore, to give satisfying taste and crunch to fried foods by using hydrogenated oils may influence the risk of several diseases like obesity, high blood pressure, high cholesterol, type-2 diabetes and heart disease, etc. [3] [4]. Recently, another concern with fried food is acrylamide, a food born chemical that forms naturally when cooked at high temperatures, believed to be metabolized to glycidamide and is a potential mutagen and as well as a reproductive toxicant [5]. At the beginning of the millennium in April 2002, the Swedish National Food Authority and the Stockholm University have first reported acrylamides formation in fried foods particularly in carbohydrate-rich products during processing [6]. Many agencies like The International Agency for Research on Cancer (IARC, 1994), The U.S. National Toxicology Program's (NTP) and The U.S. Environmental Protection Agency (EPA) have reported acrylamide as "probably carcinogenic to humans (Group 2A)" [7], "reasonably anticipated to be a human carcinogen" [8] and "likely to be carcinogenic to humans" [9], respectively; while The Food and Agriculture Organization (FAO) and the World Health Organization (WHO) have warned that the unintentional contaminant acrylamide in certain foods might be of public health concern since it has been shown to cause cancer in animals [10]. Acrylamide $\left(\mathrm{C}_{3} \mathrm{H}_{5} \mathrm{NO}\right.$; 2-propenamide), is a colorless, non-volatile crystalline solid, soluble in water and has molecular weight of $71.08 \mathrm{kDa}$ [11] [12] is formed in food at high temperature through Millard Reaction, where reducing sugar such as glucose, fructose and asparagine, an amino acid; are believed to be the major precursors. A salient reaction pathway has been proposed in Figure 1 [13] [14] [15]. In absence of asparagine, acrolein and acrylic acid, that are produced by degradation of lipids (triglycerides) due to high temperature [16] [17], and ammonia play the same role in lipid-rich foods to form acrylamide [18].

Among different validated analytical methods, gas chromatography-mass spectrometry (GC-MS) and liquid chromatography-mass spectrometry/mass spectrometry (LC-MS/MS) are found to be prominent for the estimation of acrylamides in various foods [19] [20] [21]. Elimination of potential matrix interferences by Solid phase extraction (SPE) cleanup step; reduction of ion suppression by APCI mode and no requirements of derivatization have given major advantage in LC-MS/MS over GC-MS [22]. Moreover, studies conducted by different countries like Sweden, China, Hong Kong, Austria and Turkey [23]-[27] in surveying 


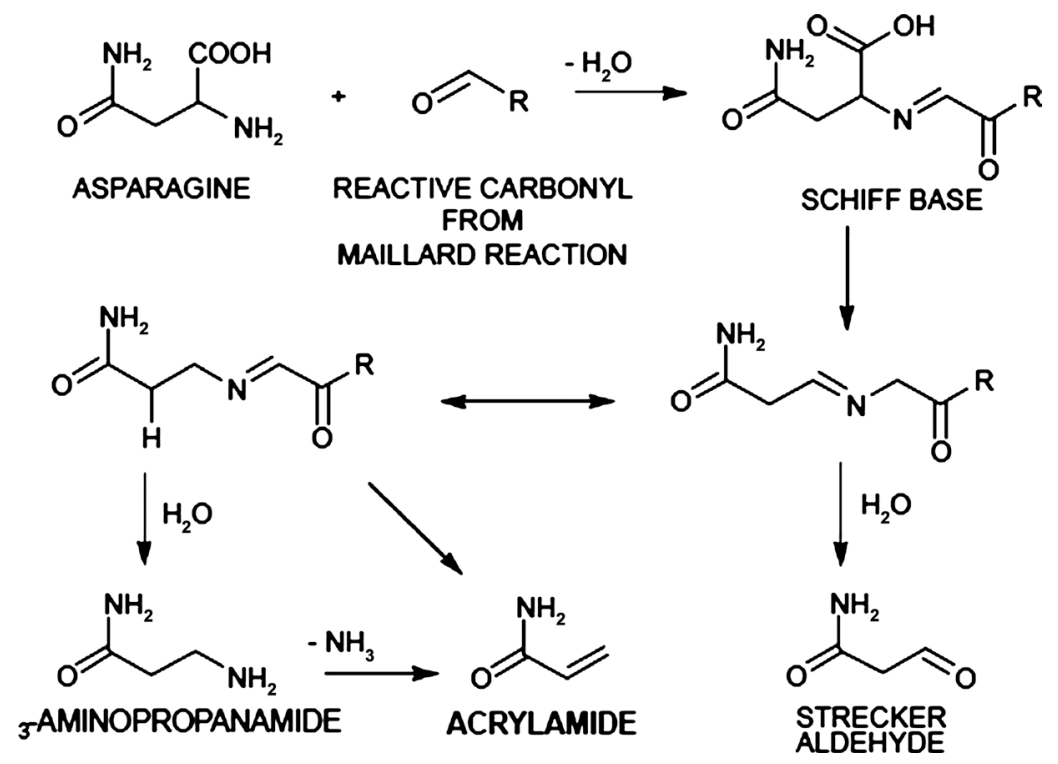

Figure 1. A salient reaction pathway for acrylamide formation in diet.

acrylamide content in various food products. However, no such study has ever been conducted in any food products in Bangladesh. Therefore, regarding the above circumstance the objective of the study was to develop a validated LC-MS/MS method for the determination of acrylamide in potato chips and other locally available foods.

\section{Experimental}

\subsection{Standards and Chemical}

Reference standard of Acrylamide (purity of 99.9\%) and isotope labelled internal standard (IS) of Acrylamide d3 were purchased from Scharlu and Sigma-Aldrich, respectively. Methanol (MS Grade, purity of 99.9\%), Acetonitrile (MS Grade, purity of 99.9\%), Hexane (HPLC grade, purity of 97.09\%) and Sodium Chloride (reagent grade, purity of $99.5 \%$ ) were procured from Sigma-Aldrich. Formic acid (purity of 98\%) analytical grade was purchased from BDH England, Magnesium Sulphate (purity of 99\%) purchased from Merck, Primary secondary amine (PSA) procured from Agilent Technologies and highest purity demineralized water was used unless mentioned otherwise.

\subsection{General Equipment}

Metler Toledo analytical AL204 balance used from (China), Hwashin sonicator bath power sonic 505 and Vortex mixer 250VM (Korea), Hermle labortechnik GmbH Centrifuge Z206A (Germany), Bibby Scientific Block heater SBH130D/3 (UK), Whatman syringe filter $0.22 \mu \mathrm{m}$ (UK) were used.

\subsection{LC-MS/MS System}

A quaternary liquid chromatographic system (Nexera X2 series) with a triple quadruple mass spectrometer-mass spectrometer equipped with an electrospray 
interface and lab solution software (LCMS-8050, Shimadzu Corporation, Japan) were used in this study.

\subsection{LC Condition}

For acrylamide analysis Phenomenex C-18 $(100 \times 2.0 \mathrm{~mm}, 2.5 \mu \mathrm{m})$ column was used which maintained at $40^{\circ} \mathrm{C}$; mobile phase was mixture of two solution with gradient elution mode: $\mathrm{B} \%: 1 \%$ (0 to $4.4 \mathrm{~min}$ )-80\% (4.5 to $5.4 \mathrm{~min}$ )- $1 \%$ (5.5 to 10 $\mathrm{min}$ ) and delivered at flow rate of $0.2 \mathrm{~mL} /$ minutes; chromatographic injection volume was $10 \mu \mathrm{L}$ and the retention time of acrylamide was about 1.8 minutes.

\subsection{MS Conditions}

The MS acquisition parameters were as follows: Run time: 10 minutes; Ion polarity: positive ion mode; ion source: atmospheric pressure electrospray ionisation; Capillary voltage $(\mathrm{kV}): 4.0$; Block temperature: $400^{\circ} \mathrm{C}$; Dessolvation line temperature: $200^{\circ} \mathrm{C}$; CID gas: Argon $(270 \mathrm{kPa})$, Nebulizing gas flow: N2, 1.5 L/min; Drying gas flow: N2, $10.0 \mathrm{~L} / \mathrm{min}$; Heating gas flow: $10 \mathrm{~L} / \mathrm{min}$; Interface temperature: $300^{\circ} \mathrm{C}$; mass spectrum scan range $(\mathrm{m} / \mathrm{z}): 10$ - $200 \mathrm{Da}$ where protonated precursor ions of acrylamide and acrylamide- $\mathrm{d}_{3}$ (IS) was $\mathrm{m} / \mathrm{z} 72.1$ and $\mathrm{m} / \mathrm{z}$ 75.1 respectively. Two multiple reactions monitoring (MRM) transitions of acrylamide and acrylamide- $\mathrm{d}_{3}$ were selected using a dwell time of 100 milli second as quantifier and confirmation ions as shown in below Table 1.

\subsection{Preparation of Mobile Phase}

Water and $0.1 \%$ formic acid in methanol were used as mobile phase. Both the solutions were degassed by sonication using ultra sonic bath and filtered through $0.22 \mu \mathrm{m}$ filter membrane using the Millipore filtration unit.

\subsubsection{Preparation of Stock Solution}

$1000 \mathrm{mg} / \mathrm{L}$ of acrylamide standard and $1.0 \mathrm{mg} / \mathrm{L}$ of IS stock solution were prepared standard in water. Both the solutions were sonicated for 10 minutes and stored at $2^{\circ} \mathrm{C}-8^{\circ} \mathrm{C}$ for further preparation of calibration solutions.

\subsubsection{Preparation of Intermediate Stock Solution}

Intermediated stock solution of $10 \mathrm{mg} / \mathrm{L}$ and $1.0 \mathrm{mg} / \mathrm{L}$ of acrylamide and IS respectively were prepared by appropriate dilution of stock solutions with water.

Table 1. Multiple Reaction Monitoring (MRM) Transition of Acrylamide and IS.

\begin{tabular}{ccccc}
\hline \multirow{2}{*}{ Name } & MRM $(\mathrm{m} / \mathbf{z})$ & \multicolumn{3}{c}{ CID Voltage $(\mathrm{V})$} \\
\cline { 3 - 5 } & $75.1>58.0^{*}$ & -29 & -15 & Q1 \\
\hline \multirow{2}{*}{ Acrylamide-d } & & -29 & -24 & -30 \\
& $75.1>30.1$ & -17 & -16 & -25 \\
Acrylamide & $72.1>55.0^{*}$ & -17 & -22 & -30 \\
\hline
\end{tabular}

${ }^{\star} \mathrm{MRM}$ transition as quantifier. 
These were also undergone sonication for 10 minutes.

\subsubsection{Preparation of Working Solution}

$1000 \mu \mathrm{g} / \mathrm{L}, 800 \mu \mathrm{g} / \mathrm{L}, 500 \mu \mathrm{g} / \mathrm{L}, 200 \mu \mathrm{g} / \mathrm{L}, 100 \mu \mathrm{g} / \mathrm{L}, 20 \mu \mathrm{g} / \mathrm{L} \& 10 \mu \mathrm{g} / \mathrm{L}$ of acrylamide and $100 \mu \mathrm{g} / \mathrm{L}$ of IS standard were prepared by appropriate dilution of intermediated stock solutions. Prepared IS standard solution was added to each acrylamide standards in 50:50 ratio to prepare $500 \mu \mathrm{g} / \mathrm{L}, 400 \mu \mathrm{g} / \mathrm{L}, 250$ $\mu \mathrm{g} / \mathrm{L}, 100 \mu \mathrm{g} / \mathrm{L}, 50 \mu \mathrm{g} / \mathrm{L}, 10 \mu \mathrm{g} / \mathrm{L}$ and $5 \mu \mathrm{g} / \mathrm{L}$ acrylamide calibration solutions where $50 \mu \mathrm{g} / \mathrm{L}$ of IS was present in each of those. All the calibration standards were sonicated for 10 minutes in ultrasonic bath and then injected into LC-MS/MS for analysis.

\subsection{Sample Preparation}

A modified QuEChERS procedure was adopted in acrylamide extraction. Accurately weighed 2 grams of crushed powder sample were weighed accurately and taken into a $50 \mathrm{~mL}$ centrifuge tube in which $5 \mathrm{~mL}$ hexane, $10 \mathrm{~mL}$ water and 10 $\mathrm{mL}$ acetonitrile were introduced. Vigorously vortexed and shook for 2 minutes. The purpose of hexane was to defat the samples and to remove oils \& non-polar components. Then Q-sep Q 100 Packet extraction salt (containing 4 g MgSO$_{4}$ and $0.5 \mathrm{~g} \mathrm{NaCl}$ ) and additional $4 \mathrm{~g}$ of $\mathrm{MgSO}_{4}$ was added to absorb the water completely. Vortexed and shook again for another 5 minutes. $2 \mathrm{~mL}$ extract from the bottom layer was transferred into another $20 \mathrm{~mL}$ centrifuge tube were 100 mg primary secondary amine (PSA) was added to remove organic acids. Vortexed for 1 minute and then centrifuged at $11,000 \mathrm{rpm}$ for 10 minutes. $1 \mathrm{~mL}$ aliquot was collected and evaporated to dryness under N2 stream. The dried sample was reconstituted with $1 \mathrm{ml}$ of water and filtrated through $0.22 \mu \mathrm{m}$ syringe filter. Then prepared sample solution and $100 \mathrm{ppb}$ of IS was mixed in 50:50 ratio in a vial. This reconstituted solution and $100 \mu \mathrm{g} / \mathrm{L}$ IS mixed in 50:50 ratio was injected into LC-MS/MS for the determination of acrylamide in the sample.

\subsection{Method Validation}

The validation of LC-MS/MS method is performed using blank sample of potato chips as per guidelines of International Conference on Harmonization [28] with various parameters such as Specificity, Linearity, Precision, Accuracy, LOD, LOQ and Robustness.

\subsubsection{Specificity or Selectivity}

Selectivity of this method was demonstrated by making $5 \mu \mathrm{g} / \mathrm{L}$ and $250 \mu \mathrm{g} / \mathrm{L}$ acrylamide standard with acetonitrile instead of water and then analyzed by LC-MS/MS. The \% RSD of retention time and area from six repeated injections at each concentration was calculated.

\subsubsection{Linearity}

Linearity was carried out at seven concentration levels ranging from 5 to 500 $\mu \mathrm{g} / \mathrm{L}$. A calibration curve was obtained by plotting the peak area vs. concentra- 
tion. The \% RSD from three repeated injections at each concentration and \% $y$-intercept bias was calculated.

\subsubsection{Accuracy}

The accuracy of the method was evaluated at three concentration levels of acrylamide (250, 400 and $500 \mu \mathrm{g} / \mathrm{L}$ ) by spiking into samples. The $\%$ recoveries reflect an average of six analyses at each concentration and \% RSD was reported.

\subsubsection{Precision}

Precision was measured as intra-day precision (repeatability) and inter-day precision (reproducibility) of working standard. The intra-day and inter-day precision of the method was demonstrated by injection (in six analyses) of the standard on two consecutive days and \% of RSD was calculated.

\subsubsection{Limit of Detection (LOD) and Limit of Quantification (LOQ)}

The LOD and LOQ of the method were estimated on the basis of signal-to-noise ratio 3:1 and 10:1, respectively by injection series of diluted solution of known concentration. The \% RSD from the six repeated injections was calculated.

\subsubsection{Robustness}

Robustness was studied at seven different concentration of acrylamide with change in some parameters such as column temperature, column type, injection volume and analyst. Percentage (\%) RSD from six repeated injections at each concentration under change condition was calculated.

\subsection{Quantification of Acrylamide in Different Types of Foods}

Besides method validation, 24 types of food total 265 items of different batches represent the whole population, manufactured by different companies without revealing their names were collected in mid April 2017 from the local market randomly and prepared according to section 2.6 for quantification of acrylamide.

\section{Results \& Discussion}

\subsection{Method Development and Optimization}

Chromatographic conditions like mobile phase composition, injection volume, flow rate and column oven temperature were optimized for better quantification of acrylamide in complex food matrix. Acrylamide exhibits both weakly acidic and basic properties. However, solubility varies considerably in polar and unipolar solvents whereas acrylamide is extremely high soluble in water [29] [30] and became fully protonated in the mobile phase. Method development under gradient conditions with different proportions of organic modifier was tried with change of flow rates for good separation of acrylamide. Finally, the mentioned composition of mobile phase and elution mode at flow rate $0.2 \mathrm{~mL} / \mathrm{min}$ was found satisfactory. The optimized $10 \mu \mathrm{L}$ injection volume, Phenomenex $\mathrm{C}-18$ column and $40^{\circ} \mathrm{C}$ column oven temperature returned the best result in separation of matrix with very little interferences and elution at about 1.8 minutes. 
Atmospheric pressure electrospray ionization used as ion source for the determination of acrylamide, gave high intensity and good linearity of calibration curve. The parent and product ions were first optimized by injecting a $500 \mu \mathrm{g} / \mathrm{L}$ standard solution of acrylamide in both positive and negative polarity mode. Due to protonation and use of formic acid in mobile phase, the intensity was much higher in positive mode. Quantification of acrylamide was performed by using optimized MRM mode for consistent and adequate response where most abundant product ions $\mathrm{m} / \mathrm{z} 55.0$ and $\mathrm{m} / \mathrm{z} 27.1$ for the case of acrylamide precursor ion $\mathrm{m} / \mathrm{z} 72.1$ were observed by employing $16 \mathrm{eV}$ and $22 \mathrm{eV}$ collision energy, respectively. On the other side product ions at $\mathrm{m} / \mathrm{z} 58.0$ and $\mathrm{m} / \mathrm{z} 30.1$ was observed in the case of acrylamide- $\mathrm{d}_{3}$ (IS) precursor $\mathrm{m} / \mathrm{z} 75.1$ by applying $15 \mathrm{eV}$ and $24 \mathrm{eV}$ collision energy, respectively. Figure 2 and Figure 3 represent the total ion chromatogram and mass spectra of product inos for acrylamide and acrylamide- $\mathrm{d}_{3}$ (IS), respectively.

\subsection{Method Performance Characteristics/Validation}

\subsubsection{Linearity}

A seven-point calibration curve was constructed by plotting triplicate injected acrylamide concentration versus area over the range of 5 to $500 \mu \mathrm{g} / \mathrm{L}$ with a mean correlation coefficient $\left(\mathrm{r}^{2}\right)$ was 0.9997 . The $\%$ RSD values of the repeated injection are $<2 \%$ within each concentration and the $\mathrm{Y}$-intercept bias is less than $2 \%$ which explains excellent linearity of the curve (Figure 4 ).

\subsubsection{Precision}

The precision was evaluated as the repeatability by calculating the percent relative

\section{Segment\#1}

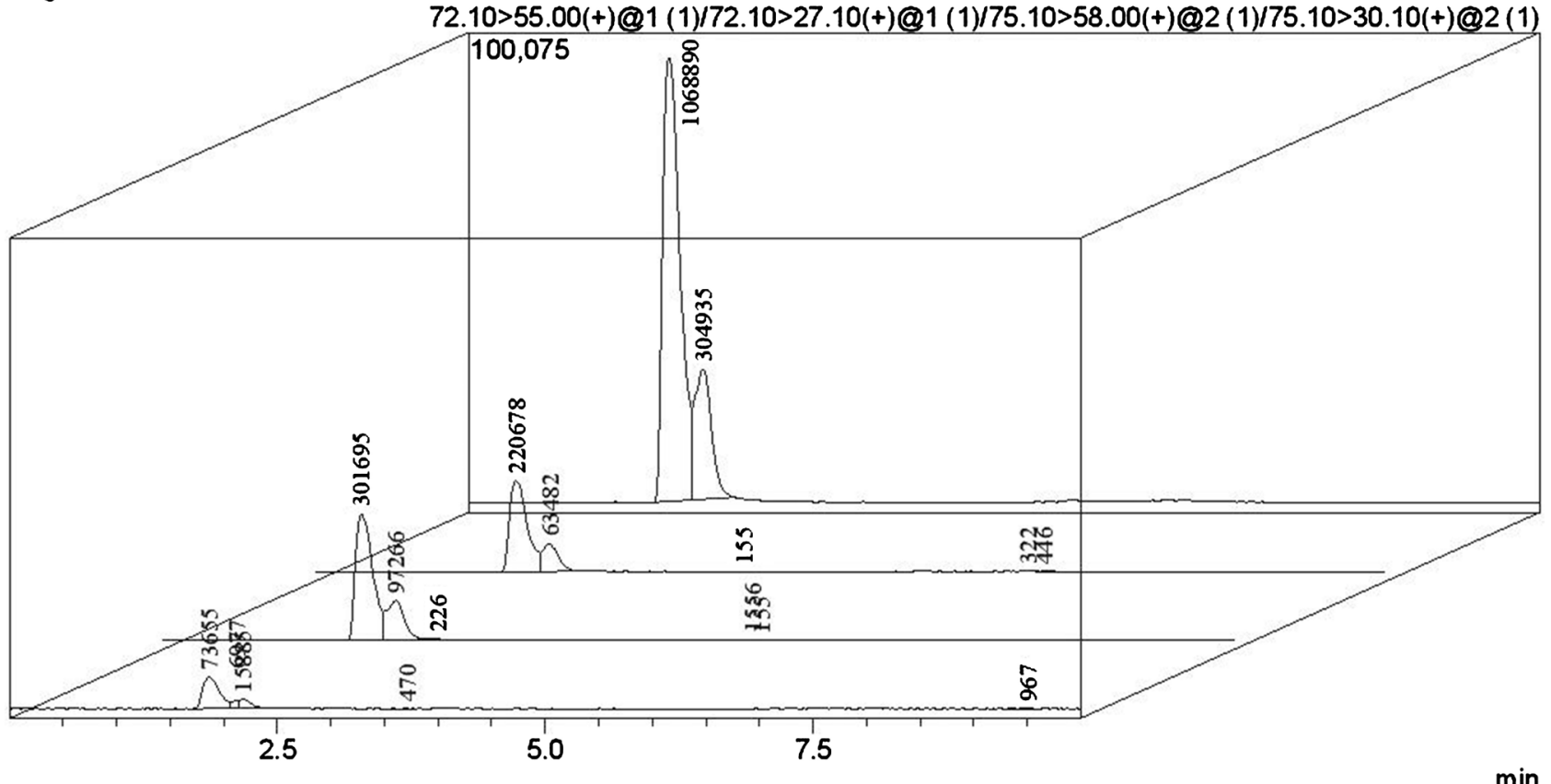

Figure 2. Breakdown of IS and Acrylamide by LC-MS/MS. 


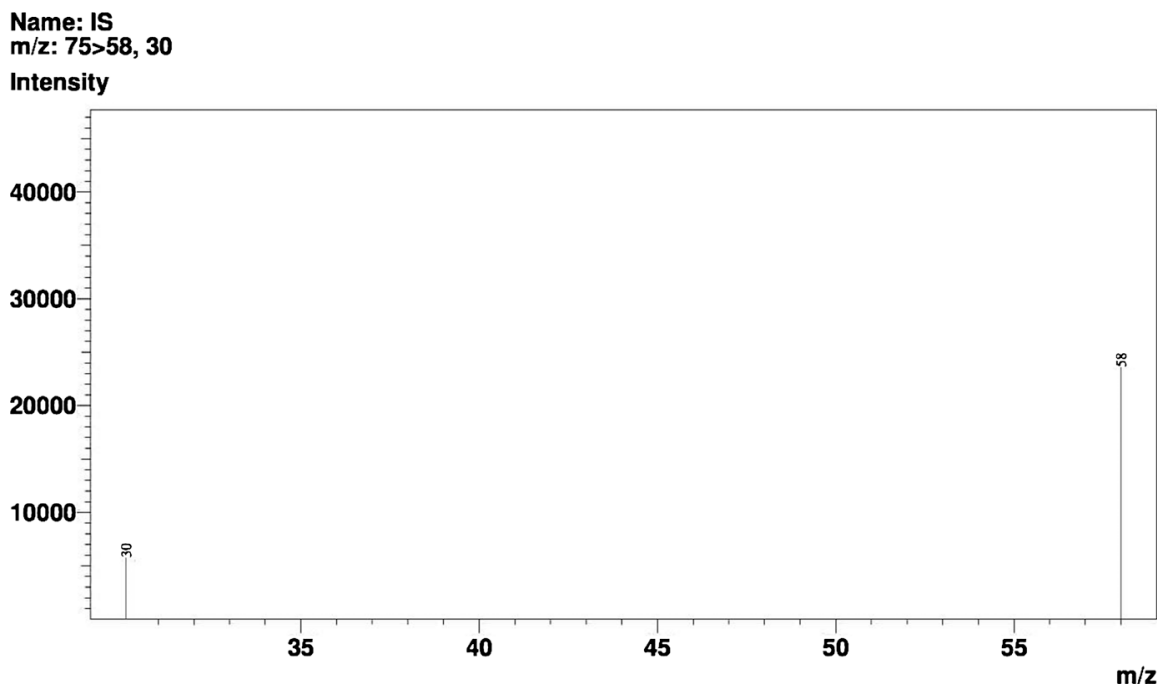

(a)

Name: Acrylamide

Mass Spectrum

$\mathrm{m} / \mathrm{z}: \mathbf{7 2 > 5 5 , 2 7}$

Intensity

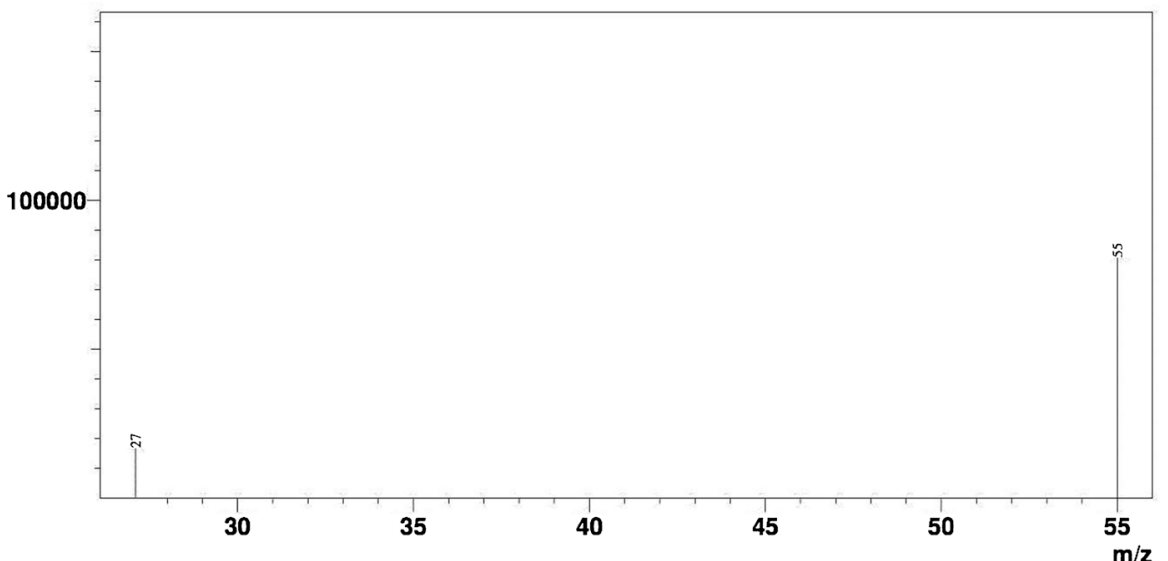

(b)

Figure 3. Mass spectra of product ion for (a) acrylamide- $\mathrm{d}_{3}$ (IS) (b) Acrylamide standard.

standard deviation (\% RSD) for six determinations each for seven different solutions which were analyzed by three different analysts on the same day (Intra-day) and on the three different days (Inter-Day) as well (Table 2). Since the $\%$ RSD value is within the acceptable norms $(<5)$ obtained for Intra-day and Inter-day at seven different concentrations, it can be said that the proposed method can be implemented for analysis.

\subsubsection{Accuracy}

The accuracy of the method was assessed by spiking different known concentration of acrylamide standard solution into sample. Standard solution of $250 \mu \mathrm{g} / \mathrm{L}$, $400 \mu \mathrm{g} / \mathrm{L}$ and $500 \mu \mathrm{g} / \mathrm{L}$ was spiked into previously analyzed sample contained $7.05 \mu \mathrm{g} / \mathrm{L}$ acrylamide. The calculated and observed concentration of acrylamide was compared and recoveries of each spiked levels were determined (Table 3). It was found that the recoveries and \% RSD for different spiked concentration laid 


\section{Calibration Curve}

$\begin{array}{lll}\text { Name } & : \text { Acrylamide, } \quad \mathrm{m} / \mathrm{z} & : 72.10>55.00 \\ \text { Quantitative Method } & : \text { Internal Standard } \\ \text { Function } & : \mathrm{f}(\mathrm{x})=0.364879 * \mathrm{x}+0.0610482 \\ \text { Correlation Coefficient }=0.9998715 & \\ \text { FitType } & : \text { Linear } \\ \text { ZeroThrough } & : \text { Not Through }\end{array}$

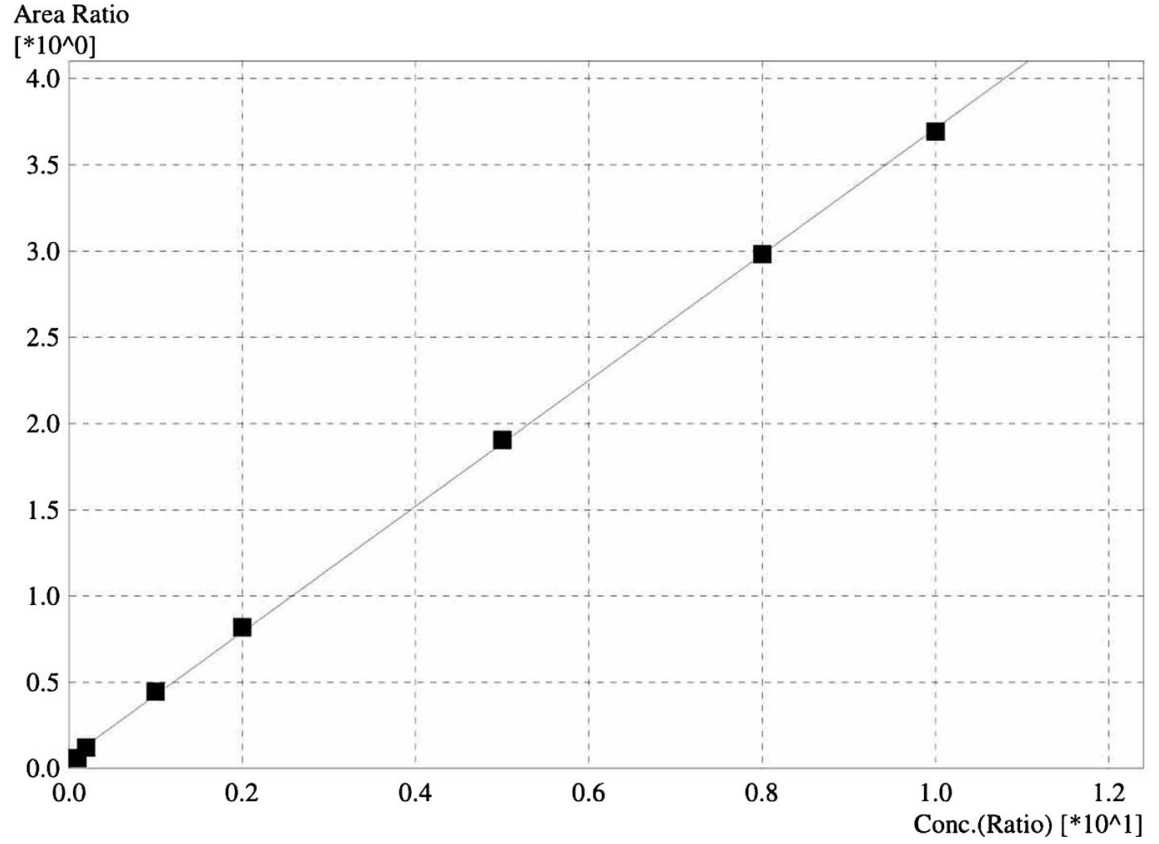

Figure 4. Calibration curve for acrylamide from 5 to $500 \mu \mathrm{g} / \mathrm{L}$.

Table 2. Precision studies for acrylamide determination.

\begin{tabular}{|c|c|c|c|c|c|c|c|c|}
\hline \multirow{2}{*}{$\begin{array}{c}\text { Standard } \\
\text { Conc. } \\
(\mu \mathrm{g} / \mathrm{L})\end{array}$} & \multicolumn{2}{|c|}{ Intra-day precision } & \multicolumn{6}{|c|}{ Inter-day precision } \\
\hline & $\begin{array}{l}\text { Mean observed conc. } \\
\qquad(\mu \mathrm{g} / \mathrm{L})(\mathrm{n}=6)\end{array}$ & $\% \mathrm{RSD}$ & Days & Analyst & $\begin{array}{l}\text { Mean observed conc. } \\
\qquad(\mu \mathrm{g} / \mathrm{L})(\mathrm{n}=6)\end{array}$ & $\begin{array}{l}\text { Mean observed conc. } \\
\qquad(\mu \mathrm{g} / \mathrm{L})(3 \text { days })\end{array}$ & $\%$ RSD & $\begin{array}{c}\text { Mean \% } \\
\text { RSD }\end{array}$ \\
\hline \multirow{3}{*}{5} & \multirow{3}{*}{5} & \multirow{3}{*}{1.73} & Day 1 & Analyst-1 & 4.804 & \multirow{3}{*}{4.92} & 3.871 & \multirow{3}{*}{2.19} \\
\hline & & & Day 2 & Analyst-2 & 4.95 & & 1.977 & \\
\hline & & & Day 3 & Analyst-3 & 5.00 & & 0.716 & \\
\hline \multirow{3}{*}{10} & \multirow{3}{*}{10.55} & \multirow{3}{*}{2.20} & Day 1 & Analyst-1 & 9.95 & & 1.169 & \multirow{3}{*}{2.23} \\
\hline & & & Day 2 & Analyst-2 & 9.80 & 9.87 & 2.730 & \\
\hline & & & Day 3 & Analyst-3 & 9.85 & & 2.779 & \\
\hline \multirow{3}{*}{50} & \multirow{3}{*}{50.65} & \multirow{3}{*}{0.95} & Day 1 & Analyst-1 & 49.45 & & 3.287 & \multirow{3}{*}{1.62} \\
\hline & & & Day 2 & Analyst-2 & 49.7 & 49.73 & 1.643 & \\
\hline & & & Day 3 & Analyst-3 & 50.05 & & 1.984 & \\
\hline \multirow{3}{*}{100} & \multirow{3}{*}{98.25} & \multirow{3}{*}{1.84} & Day 1 & Analyst-1 & 99.1 & & 1.248 & \multirow{3}{*}{2.00} \\
\hline & & & Day 2 & Analyst-2 & 99.2 & 99.43 & 1.587 & \\
\hline & & & Day 3 & Analyst-3 & 100 & & 3.142 & \\
\hline
\end{tabular}




\section{Continued}

\begin{tabular}{|c|c|c|c|c|c|c|c|c|}
\hline & & & Day 1 & Analyst-1 & 248.8 & & 0.368 & \\
\hline \multirow[t]{3}{*}{250} & 247.1 & 1.28 & Day 2 & Analyst-2 & 246.05 & 247.42 & 1.521 & 1.25 \\
\hline & & & Day 3 & Analyst-3 & 247.4 & & 1.833 & \\
\hline & & & Day 1 & Analyst-1 & 393.25 & & 2.522 & \\
\hline \multirow[t]{3}{*}{400} & 395.9 & 0.70 & Day 2 & Analyst-2 & 391.95 & 393.38 & 2.125 & 1.84 \\
\hline & & & Day 3 & Analyst-3 & 394.95 & & 0.890 & \\
\hline & & & Day 1 & Analyst-1 & 486.45 & & 1.532 & \\
\hline \multirow[t]{2}{*}{500} & 496.4 & 0.54 & Day 2 & Analyst-2 & 481.55 & 480.63 & 1.338 & 1.40 \\
\hline & & & Day 3 & Analyst-3 & 473.9 & & 1.338 & \\
\hline
\end{tabular}

Table 3. Accuracy studies for acrylamide determination.

\begin{tabular}{ccccccc}
\hline $\begin{array}{c}\text { Acrylamide } \\
\text { standard } \\
\text { Conc. }(\mu \mathrm{g} / \mathrm{L})\end{array}$ & $\begin{array}{c}\text { Observed Conc. of } \\
\text { Acrylamide standard } \\
(\mu \mathrm{g} / \mathrm{L})(\mathrm{n}=3)\end{array}$ & $\begin{array}{c}\text { Analyte Conc. in } \\
\text { sample }(\mu \mathrm{g} / \mathrm{L})(\mathrm{n}=6)\end{array}$ & $\begin{array}{c}\text { Total Conc. (Analyte Conc. in } \\
\text { sample + Acrylamide standard } \\
\text { Conc. })(\mu \mathrm{g} / \mathrm{L})\end{array}$ & $\begin{array}{c}\text { Observed Conc. in } \\
\text { sample after spiking } \\
(\mu \mathrm{g} / \mathrm{L})(\mathrm{n}=6)\end{array}$ & $\begin{array}{c}\text { \% Recovery } \\
\text { \% RSD }\end{array}$ \\
\hline 250 & 265.9 & & 272.95 & 261.55 & 104.36 & 0.96 \\
400 & 398.45 & 7.05 & 405.5 & 410.7 & 98.73 & 1.08 \\
500 & 489.1 & & 496.15 & 511.85 & 96.93 & 0.81 \\
\hline
\end{tabular}

between the range of $96 \%-105 \%$ and $0.8-1.1$, respectively; which is within the acceptable norms signifying the accuracy of the method.

\subsubsection{Selectivity}

Selectivity of this method was demonstrated in the presence of acetonitrile instead of water. Six repeated injections of $5 \mu \mathrm{g} / \mathrm{L}$ and $250 \mu \mathrm{g} / \mathrm{L}$ of acrylamide standard prepared in acetonitrile along with $50 \mu \mathrm{g} / \mathrm{L}$ IS were analyzed by LC-MS/MS. A slight change at elution time (1.7 minutes) of acrylamide was observed with \% RSD of only 0.17 to 0.23 , which demonstrates that the method is selective and interferences free (Figure 5).

\subsubsection{LOD \& LOQ}

LOD (Limit of Detection) is the lowest detectable but not quantifiable target analyte concentration and LOQ (Limit of Quantitation) is the lowest quantifiable concentration of target analyte with acceptable precision; was determined by considering signal to noise ratio $(\mathrm{S} / \mathrm{N})$ of the strongest mass transition with respect to background noise obtained from the blank (Figure 6). Signal to noise ratio $(\mathrm{S} / \mathrm{N})$ of 3:1 was taken for LOD whereas it was 6:1 for LOQ. Based on this ratio, the LOD and LOQ for acrylamide were obtained as $2.0 \mu \mathrm{g} / \mathrm{L}$ and $4.0 \mu \mathrm{g} / \mathrm{L}$ respectively with \%RSD less than 5 for six replicates.

\subsubsection{Robustness}

By analyzing seven different concentration of acrylamide with change in some parameters such as column temperature, column type, injection volume and different analyst; the robustness of method was determined (Table 4). The 


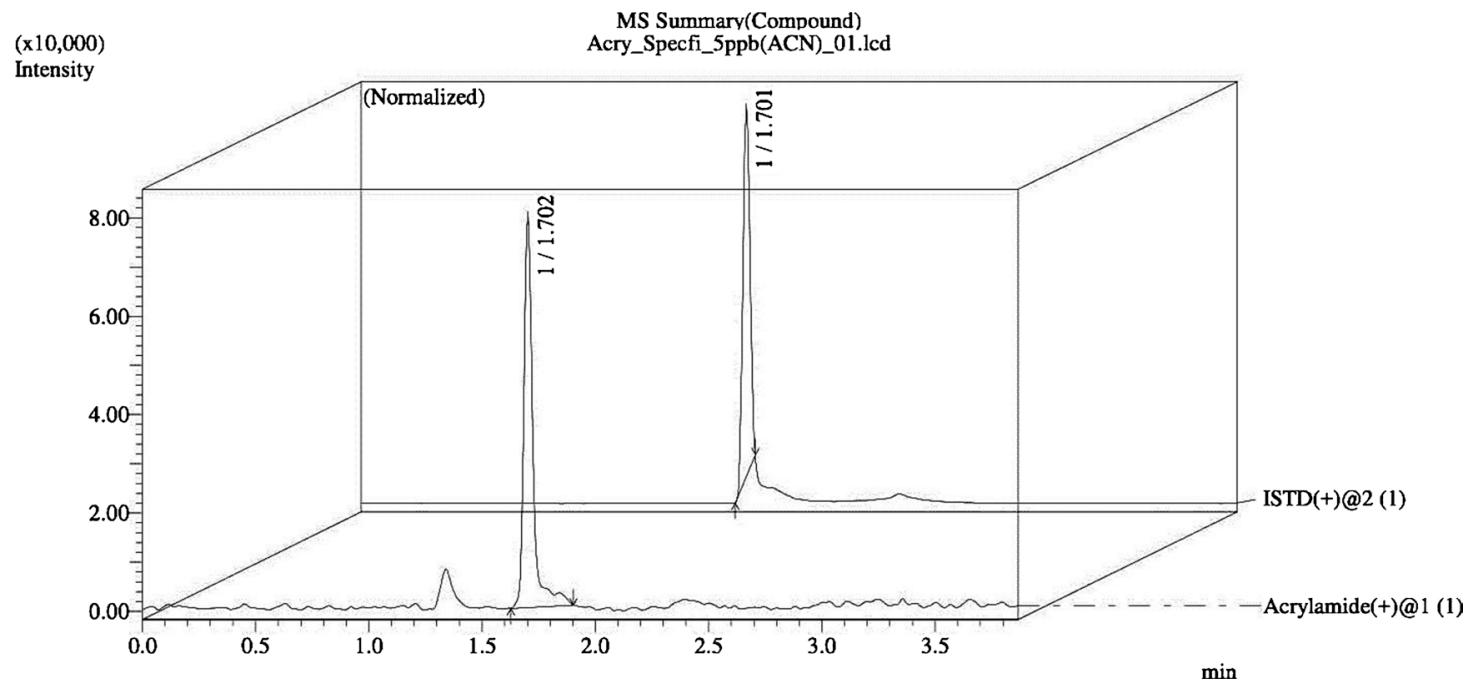

(a)

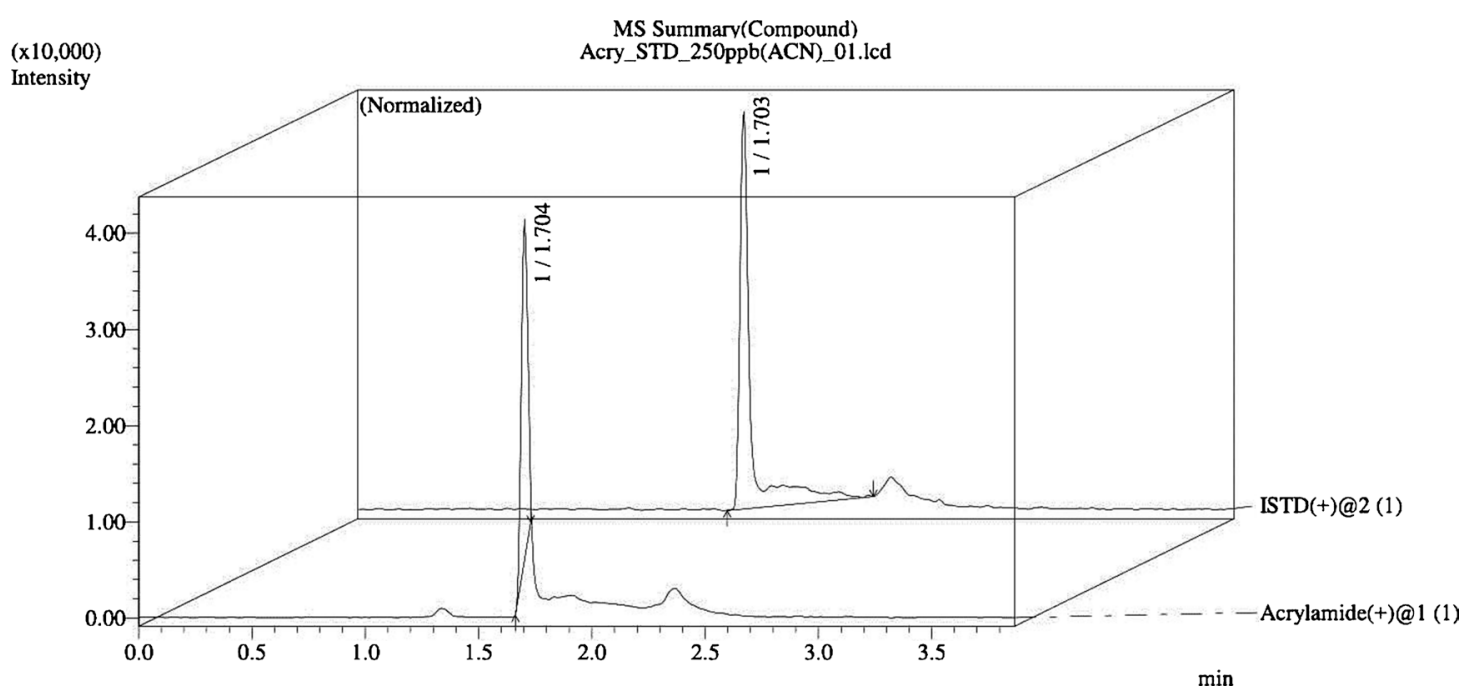

(b)

Figure 5. Total ion chromatogram of selectivity study where acetonitrile was used to analyze the effect on acrylamide standard.

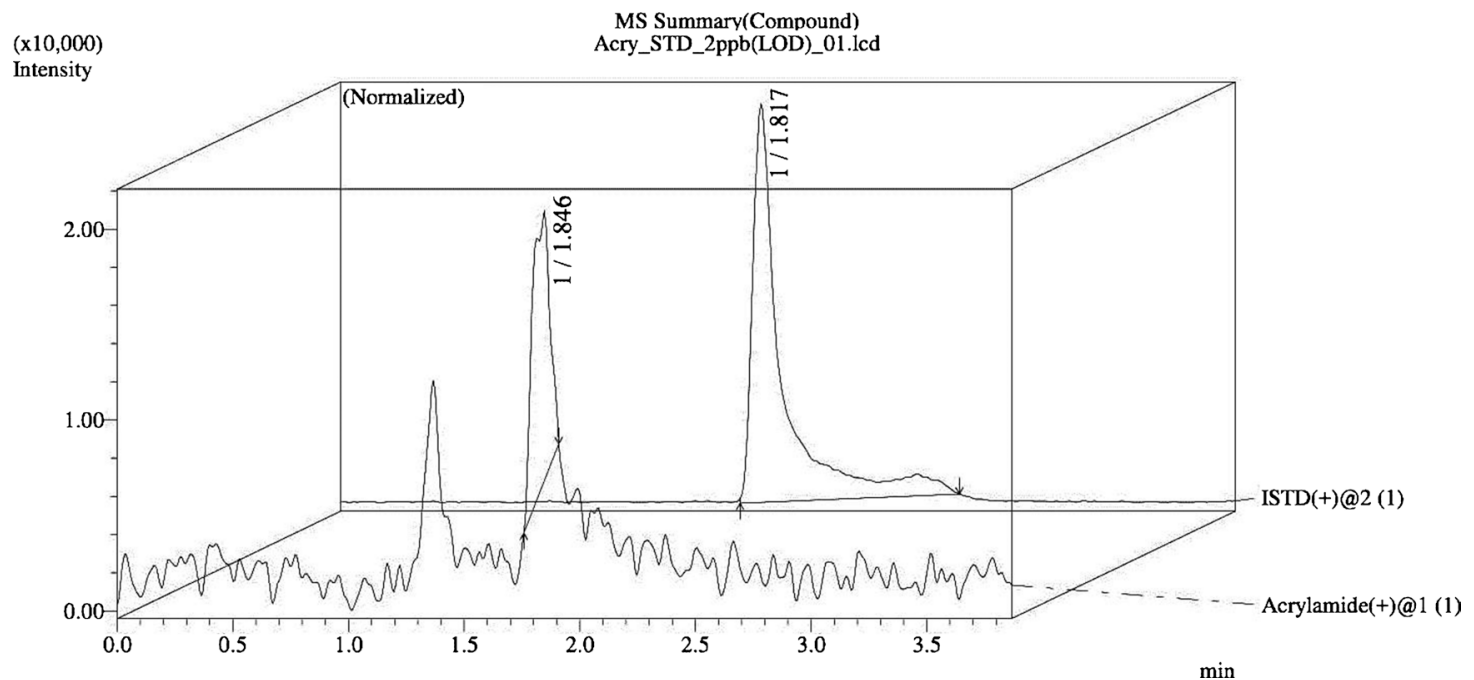

(a) 


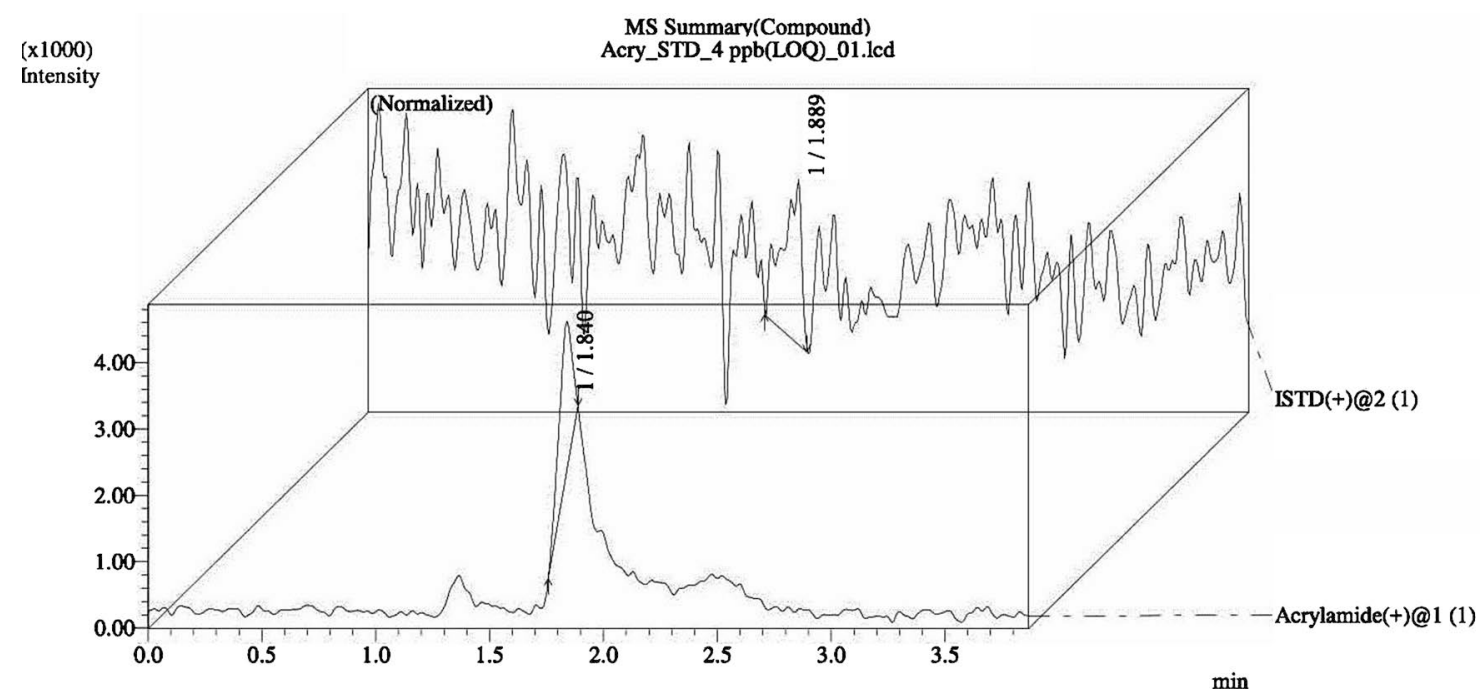

(b)

Figure 6. Chromatogram of (a) LOD and (b) LOQ for Acrylamide along with IS.

Table 4. Robustness studies for acrylamide determination under changed conditions.

\begin{tabular}{|c|c|c|c|c|c|c|c|c|c|c|}
\hline \multirow{3}{*}{$\begin{array}{l}\text { Acrylamide } \\
\text { standard } \\
\text { concentratio } \\
\mathrm{n}(\mu \mathrm{g} / \mathrm{L})\end{array}$} & \multicolumn{2}{|c|}{ Developed method } & \multicolumn{8}{|c|}{ Change in operational method } \\
\hline & \multirow{2}{*}{$\begin{array}{l}\text { Mean Conc. } \\
\qquad(\mu \mathrm{g} / \mathrm{L}) \\
(\mathrm{n}=6)\end{array}$} & \multirow{2}{*}{ RSD \% } & \multicolumn{2}{|c|}{$\begin{array}{c}\text { Column (Shim-pack XR-ODS } \\
\text { II, C18, } 2.0 \mathrm{~mm} \times 100 \mathrm{~mm} \text {, } \\
2.2 \mu)\end{array}$} & \multicolumn{2}{|c|}{$\begin{array}{l}\text { Column temparature } \\
\qquad\left(35^{\circ} \mathrm{C}\right)\end{array}$} & \multicolumn{2}{|c|}{$\begin{array}{l}\text { Injection volume } \\
\qquad(10 \mu \mathrm{l})\end{array}$} & \multicolumn{2}{|c|}{ Analyst II } \\
\hline & & & $\begin{array}{c}\text { Mean Conc. }(\mu \mathrm{g} / \mathrm{L}) \\
(\mathrm{n}=3)\end{array}$ & RSD \% & $\begin{array}{l}\text { Mean Conc. } \\
(\mu \mathrm{g} / \mathrm{L})(\mathrm{n}=3)\end{array}$ & RSD \% & $\begin{array}{l}\text { Mean Conc. } \\
(\mu \mathrm{g} / \mathrm{L})(\mathrm{n}=3)\end{array}$ & RSD \% & $\begin{array}{l}\text { Mean Conc. } \\
(\mu \mathrm{g} / \mathrm{L})(\mathrm{n}=3)\end{array}$ & RSD \% \\
\hline 5 & 5.00 & 1.73 & 4.65 & 2.75 & 5.0 & 1.49 & 5.0 & 1.49 & 5.0 & 1.49 \\
\hline 10 & 10.55 & 2.20 & 9.65 & 3.82 & 9.85 & 3.80 & 9.85 & 3.80 & 9.85 & 3.80 \\
\hline 50 & 50.65 & 0.95 & 50.8 & 1.16 & 47.15 & 2.39 & 47.15 & 2.39 & 47.15 & 2.39 \\
\hline 100 & 98.25 & 1.84 & 100.7 & 1.15 & 98.4 & 3.32 & 98.4 & 3.32 & 98.4 & 3.32 \\
\hline 250 & 247.1 & 1.28 & 249.7 & 1.92 & 254.35 & 1.00 & 254.35 & 1.00 & 254.35 & 1.00 \\
\hline 400 & 395.9 & 0.70 & 401.7 & 0.09 & 399.55 & 1.17 & 399.55 & 1.17 & 399.55 & 1.17 \\
\hline 500 & 496.4 & 0.54 & 480.3 & 4.55 & 497.45 & 1.46 & 497.45 & 1.46 & 497.45 & 1.46 \\
\hline
\end{tabular}

acrylamide content obtained by the developed method and that obtained under the mentioned change conditions, remained almost the same with \% RSD less than 4.0 in every case.

\subsection{Quantification of Acrylamide in Other Foods}

The developed validate method of acrylamide quantification in potato chips by LC-MS/MS was also applied to analyze in other 265 food items like french fry, beef tikka, peyaju, chicken grill, flour chips, potato Biscuits, chanachur, cheese, puffs, coffee candy, chicken fry, puri, shik kabab, fuska, bread, brinjal fry, nut without shell, nut with shell, chicken nuggets etc. as shown in Table 5 and the frequency distribution of acrylamide content in foods is illustrated in Figure 7. $77 \%$ of the analyzed samples have returned positive levels of acrylamide ranging 
Table 5. The acrylamide contents in foods using LC/MS/MS methods.

\begin{tabular}{|c|c|c|c|c|c|c|}
\hline \multirow{2}{*}{ Item } & \multirow{2}{*}{$\begin{array}{l}\text { Number } \\
\text { of Sample }\end{array}$} & \multirow{2}{*}{$\begin{array}{l}\text { Samples } \\
\text { positive }\end{array}$} & \multicolumn{4}{|c|}{ Level of Acrylamide $(\mu \mathrm{g} / \mathrm{L})$} \\
\hline & & & Min. & Max. & Mean & SD \\
\hline Potato chips & 52 & 44 & 44.97 & 252.79 & 131.48 & 62.78 \\
\hline French fry & 43 & 43 & 162.63 & 244.67 & 197.04 & 22.92 \\
\hline Beef tikka & 10 & 10 & 41.27 & 87.71 & 60.33 & 15.58 \\
\hline Peyaju & 13 & 13 & 51.09 & 113.17 & 82.47 & 16.30 \\
\hline Chicken grill & 11 & 11 & 142.72 & 169.98 & 156.29 & 9.45 \\
\hline Flour chips & 5 & 5 & 18.12 & 25.17 & 21.19 & 2.82 \\
\hline Potato Biscuits & 5 & 5 & 43.28 & 57.32 & 51.17 & 5.22 \\
\hline Chanachur & 10 & 10 & 13.66 & 23.65 & 19.33 & 3.16 \\
\hline Cheese puffs & 1 & 0 & \multicolumn{4}{|c|}{$<\mathrm{DL}$} \\
\hline Coffee candy & 1 & 0 & \multicolumn{4}{|c|}{$<\mathrm{DL}$} \\
\hline Chicken fry & 8 & 8 & 104.32 & 127.50 & 114.63 & 8.02 \\
\hline Puri & 10 & 0 & \multicolumn{4}{|c|}{$<\mathrm{DL}$} \\
\hline Shik kabab & 5 & 5 & 151.21 & 187.22 & 172.87 & 13.74 \\
\hline Fuska & 7 & 7 & 17.77 & 23.29 & 20.43 & 1.92 \\
\hline Bread & 9 & 0 & \multicolumn{4}{|c|}{$<\mathrm{DL}$} \\
\hline Brinjal fry & 10 & 10 & 20.79 & 31.49 & 25.53 & 3.61 \\
\hline Nut without shell & 5 & 0 & \multicolumn{4}{|c|}{$<\mathrm{DL}$} \\
\hline Nut with shell & 7 & 0 & \multicolumn{4}{|c|}{$<\mathrm{DL}$} \\
\hline Chicken nuggets & 5 & 0 & \multicolumn{4}{|c|}{$<\mathrm{DL}$} \\
\hline Fish fry & 10 & 10 & 74.17 & 85.27 & 79.76 & 3.67 \\
\hline Egg fry & 10 & 10 & 83.21 & 93.33 & 89.14 & 3.49 \\
\hline Boiled egg & 5 & 0 & \multicolumn{4}{|c|}{$<\mathrm{DL}$} \\
\hline Cake & 8 & 0 & \multicolumn{4}{|c|}{$<\mathrm{DL}$} \\
\hline Biscuit & 15 & 14 & 10.72 & 57.73 & 35.23 & 16.80 \\
\hline
\end{tabular}

from 19.33 to $197.04 \mu \mathrm{g} / \mathrm{L}$, among which $54 \%$ were found to be more than $100 \mu \mathrm{g} / \mathrm{L}$. Average acrylamide content in Chanachur was found to be lowest $(19.33 \mu \mathrm{g} / \mathrm{L})$ while in processed and cooked food like potato chips, french fries, Beef tikka, Peyaju, Chicken grill, Flour chips, Chicken fry, Shik kabab, fuska, Fish fry, Egg fry, Brinjal it was highest with average values of $20.43-197.04 \mu \mathrm{g} / \mathrm{kg}$.

Acrylamide contents in baked products except for biscuit and other food items like cheese puffs, coffee candy, nut without shell, nut with shell, chicken nuggets and boiled egg were found to be below the detection limit. Levels of acrylamide in protein-rich food $(79.76-89.14 \mu \mathrm{g} / \mathrm{L})$ were higher than that of baked food products (35.23 - $51.17 \mu \mathrm{g} / \mathrm{kg}$ ) indicating the occurrence of the acrylamide contamination due to cooking procedures.

Previous research also supports the above statement, that acrylamide may be 
70

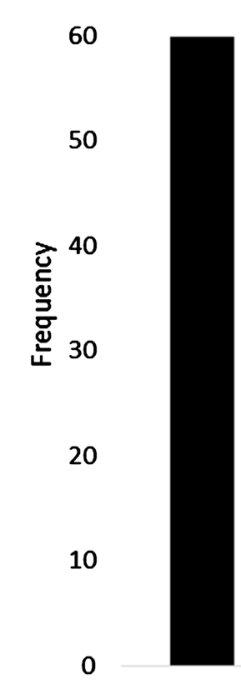

ND

\section{Frequency Distribution of Acrylamide Content}

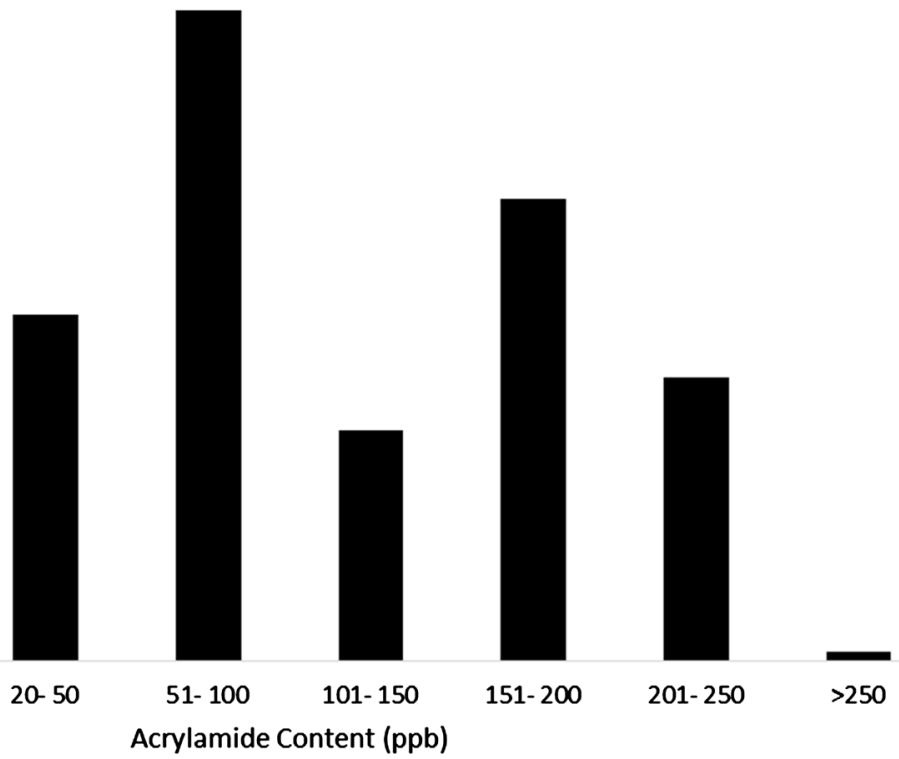

Figure 7. Frequency distribution of acrylamide content in food.

Table 6. Ranges of acrylamide in various food products [32].

\begin{tabular}{cc}
\hline Product & Acrylamide Range $\left(\mu \mathrm{g} \cdot \mathrm{Kg}^{-1}\right)$ \\
\hline Potato chips & $117-2762$ \\
French Fries & $20-1352$ \\
Breads \& bakery products & $10-364$ \\
Chocolate products & $0-909$ \\
Nuts \& nut butters & $28-457$ \\
Protein foods & $0-116$ \\
Canned fruit \& vegetables & $0-83$ \\
\hline
\end{tabular}

formed due to the differences in cooking and processing parameters, methods, type and quality of raw materials, as well as formulations [31]. The quantification of acrylamide investigated for the very first time in Dhaka, Bangladesh in different food was found to be within range and also reported by United States Food and Drug Administration (Table 6).

Though there is a declaration regarding daily allowable limit of acrylamide uptake (0.3 - $0.8 \mu \mathrm{g} / \mathrm{kg}$ body weight) [33], the allowable limit of acrylamide formation in food is yet to be set. It is high time to investigate current food processing practices or to develop new food processing techniques so that the acrylamide formation in food products can be minimized for the sake of public health especially for our future generations. 


\section{Conclusion}

The developed LC-MS/MS method for the determination of acrylamide is simple, rapid, sensitive accurate and precise and can be applicable for routine analysis. The method is mainly applicable for starch-based products but can also be adopted for other sample matrices as well. Participation in Proficiency Testing might help to get a clear view about the applicability of this method. Besides, the highest acrylamide levels were found in fried products, such as potato chips, french fries, chicken grill and sheikh kabab, which indicated the general risk on public health due to toxicity of acrylamide from foods. This investigation supplied important information on acrylamide in food for public health experts, food policy makers and consumers. Further research is suggested to find out the correlation among temperature, sugar and asparagine, and also to minimize the acrylamide formation during the processing of food.

\section{Acknowledgements}

We are great full to all employee of Designated Reference Institute for Chemical Measurements (DRiCM) for their cordial help during analysis. Additionally, M. Bruno, Mohammad Mizanur Rahman and Abdullah-al-Mamun are acknowledged for reviewing the paper.

\section{Conflicts of Interest}

All of the authors are employees of Designated Reference Institute for Chemical Measurements. The authors have no other relevant affiliations or financial involvement with any organization or entity with a financial interest in or financial conflict with the subject matter or materials discussed in the manuscript apart from those disclosed.

\section{References}

[1] Harris, R.S. (2014) General Discussion on the Stability of Nutrients. In: Karmas, E. and Harris, R.S., Eds., Nutritional Evaluation of Food Processing, Springer, Dordrecht. https://doi.org/10.1007/978-94-011-7030-7_1

[2] Ikanone, C.E.O. and Oyekan, P.O. (2014) Effect of Boiling and Frying on the Total Carbohydrate, Vitamin C and Mineral Contents of Irish (Solanun tuberosum) and Sweet (Ipomea batatas) Potato Tubers. Nigerian Food Journal, 32, 33-39. https://doi.org/10.1016/S0189-7241(15)30115-6

[3] Henry, C.J.K. (1998) Impact of Fried Foods on Macronutrient Intake, with Special Reference to Fat and Protein. Grasas y Aceites, 49, 336-339. https://doi.org/10.3989/gya.1998.v49.i3-4.736

[4] Cahill, L.E., Pan, A., Chiuve, S.E., Sun, Q., Willett, W.C., Hu, F.B. and Rimm, E.B. (2014) Fried-Food Consumption and Risk of Type 2 Diabetes and Coronary Artery Disease: A Prospective Study in 2 Cohorts of Men and US Women. The American Journal of Clinical Nutrition, 100, 667-675. https://doi.org/10.3945/ajcn.114.084129

[5] Barber, D.S., Hunt, J.R., Ehrich, M.F., Lehning, E.J. and Lo Pachin, R.M. (2011) Metabolism, Toxicokinetics and Hemoglobin Adduct Formation in Rats Following Subacute and Subchronic Acrylamide Dosing. Neurotoxicology, 22, 341-353. 
https://doi.org/10.1016/S0161-813X(01)00024-9

[6] Tareke, E., Rydberg, P., Karlsson, P., Erickson, S. and Tornqvist, M. (2001) Analysis of Acrylamide, a Carcinogen Formed in Heated Foodstuffs. Journal of Agricultural and Food Chemistry, 50, 4998-5006. https://doi.org/10.1021/jf020302f

[7] IARC (International Agency for Research on Cancer) (1994) Acrylamide in "IARC Monographs on the Evaluation of Carcinogenic Risks to Humans". Volume 60 Some Industrial Chemicals, Lyon, 389-433.

[8] NTP (2011) Report on Carcinogens. 12th Edition, U.S. National Toxicology Program, Research Triangle Park. http://ntp.niehs.nih.gov/go/roc12

[9] EPA (2011) Integrated Risk Information System (IRIS): Acrylamide (CASRN 79-06 1). United States Environmental Protection Agency, Washington DC. http://www.epa.gov/iris/subst/0286.htm

[10] Food and Agriculture Organization and World Health Organization (2005) Joint FAO/WHO Expert Committee on Food Additives (Summary and Conclusions) Sixty-Fourth Meeting. Rome, 1-47.

[11] Ashoor, S.H. and Zent, J.B. (1984) Maillard Browning of Common Amino Acids and Sugars. Journal of Food Science, 49, 1206-1207. https://doi.org/10.1111/j.1365-2621.1984.tb10432.x

[12] Eriksson, S. (2005) Acrylamide in Food Products: Identification, Formation and Analytical Methodology. Doctoral Thesis, Department of Environmental Chemistry, Stockholm University, Stockholm.

[13] Zyzak, D.V., Sanders, R.A., Stojanovic, M., Tallmadge, D.H., Eberhart, B.L., Ewald, D.K., Gruber, D.C., Morsch, T.R., Strothers, M.A., Rizzi, G.P. and Villagran, M.D. (2003) Acrylamide Formation Mechanism in Heated Foods. Journal of Agricultural and Food Chemistry, 51, 4782-4787. https://doi.org/10.1021/jf034180i

[14] Amrein, T.M., Bachmann, S., Noti, A., Biedermann, M., Barbosa, M.F., Biedermann-Brem, S., Grob, K., Keiser, A., Realini, P., Escher, F. and Amado, R. (2003) Potential of Acrylamide Formation, Sugars, and Free Asparagine in Potatoes: A Comparison of Cultivars and Farming Systems. Journal of Agricultural and Food Chemistry, 51, 5556-5560. https://doi.org/10.1021/jf034344v

[15] Yaylayan, V. and Stadler, R.H. (2005) Acrylamide Formation in Food: A Mechanistic Perspective. Journal of AOAC International, 88, 262-267.

[16] Umano, K. and Shibamoto, T. (1987) Analysis of Acrolein from Heated Cooking Oils and Beef Fat. Journal of Agriculture and Food Chemistry, 35, 909-912. https://doi.org/10.1021/jf00078a014

[17] Gertz, C. and Klostermann, S. (2002) Analysis of Acrylamide and Mechanisms of Its Formation in Deep-Fried Foods. European Journal of Lipid Science and Technology, 104, 762-771. https://doi.org/10.1002/1438-9312(200211)104:11<762::AID-EJLT762>3.0.CO;2-R

[18] Becalski, A., Lau, B.P.Y., Lewis, D., Seaman, S.W., Hayward, S., et al. (2004) Acrylamide in French Fries: Influence of Free Amino Acids and Sugars. Journal of Agricultural and Food Chemistry, 52, 3801-3806. https://doi.org/10.1021/jf0349376

[19] Yasuhara, A., Tanaka, Y., Hengel, M. and Shibamoto, T. (2003) Gas Chromatographic Investigation of Acrylamide Formation in Browning Model Systems. Journal of Agricultural and Food Chemistry, 51, 3999-4003. https://doi.org/10.1021/jf0300947

[20] Ono, H., Chuda, Y., Ohnishi-Kameyama, M., Yada, H., Ishizaka, M., Kobayashi, H. and Yoshida, M. (2003) Analysis of Acrylamide by LC/MS/MS and GC/MS in 
Processed Japanese Foods. Food Additives \& Contaminants, 20, 215-220. https://doi.org/10.1080/0265203021000060887

[21] Andrzejewski, D., Roach, J.A.G., Gay, M.L. and Musser, S.M. (2004) Analysis of Coffee for the Presence of Acrylamide by LC/MS/MS. Journal of Agricultural and Food Chemistry, 52, 1996-2002. https://doi.org/10.1021/jf0349634

[22] Pittet, A., Perisset, A. and Oberson, J.M. (2004) Trace Level Determination of Acrylamide in Cereal-Based Foods by Gas Chromatography-Mass Spectrometry. Journal of Chromatography A, 1035, 123-130. https://doi.org/10.1016/j.chroma.2004.02.037

[23] Svensoon, K., Abramsson, L., Becker, W. and Glynn, A. (2003) Dietary Intake of Acrylamide in Sweden. Food and Chemical Toxicology, 41, 1581-1586. https://doi.org/10.1016/S0278-6915(03)00188-1

[24] Cheng, W.C., Hsiao, S.W., Chou, S.S., Sun-Hwang, L., Lu, T.J. and Yeh, A.I. (2006) Determination of Acrylamide in Chinese Foods by GC-Ion Trap MS Using 2-Bromopropenamide and 2-Bromopropenamide-13C3. Journal of Food and Drug Analysis, 14, 207-214.

[25] Leung, K.S., Lin, A., Tsang, C.K. and Yeung, S.T.K. (2003) Acrylamide in Asian Foods in Hong Kong. Food Additives \& Contaminants, 20, 1105-1113. https://doi.org/10.1080/02652030310001620414

[26] Murkovic, M. (2004) Acrylamide in Austrian Foods. Journal of Biochemical and Biophysical Methods, 61, 161-167. https://doi.org/10.1016/j.jbbm.2004.02.006

[27] Şenyuva, H.Z. and Gökmen, V. (2005) Survey of Acrylamide in Turkish Foods by an In-House Validated LC-MS Method. Food Additives \& Contaminants, 22, 204-209. https://doi.org/10.1080/02652030512331344178

[28] Guidelines on Validation of Analytical Procedure: Methodology Q2R1 (2005) International Conference on Harmonization of Technical Requirements for Registration of Pharmaceuticals for Human Use. Commission of the European Communities, Geneva.

[29] American Cyanamid Co. (1969) Chemistry of Acrylamide, Bulletin PRC 109. Process Chemicals Department, American Cyanamid Co., Wayne, 1-64.

[30] Habermann, C.E. (1991) Acrylamide. In: Kroschwitz, J.J., Howe-Grant, M. and Kirk Othmer, E., Eds., Encyclopedia of Chemical Technology, 4th Edition, Vol. 1, John Wiley \& Sons, New York, 251-266.

[31] Olmez, H., Tuncay, F., Ozcan, N. and Demirel, S. (2008) A Survey of Acrylamide Levels in Foods from the Turkish Market. Journal of Food Composition and Analysis, 21, 564-568. https://doi.org/10.1016/j.jfca.2008.04.011

[32] U.S. Food and Drug Administration Center for Food Safety and Applied Nutrition [FDA/CFSAN] (2002) Exploratory Date on Acrylamide in Foods. United States Food and Drug Administration, Washington DC.

[33] World Health Organization (WHO) (2002) FAO/WHO Consultations on the Health Implications of Acrylamide in Foods. Summary Report of a Meeting Held in Geneva. 